\title{
Treatment and Control of Covid-19 (Corona Virus Disease 2019) By Non-invasive (h.i.p) Non-drug Therapy in Combination Anti- influenza an (Oseltamivir (rx) Tamiflue) Drug-Novel Case Report
}

\author{
Prof.em.Dr.Amina Ather ${ }^{*}$, Vincenzo Costigliola ${ }^{2}$ \\ ${ }^{1}$ Representative for Asian Countries, European Medical Association, Avenue des, Volontaires, Brussels, Belgium, \\ European Union \\ ${ }^{2}$ President, European Medical Association, Avenue des Volontaires, Brussels, Belgium, European Union
}

\begin{abstract}
*Address for Correspondence: Prof.em.Dr.AminaAther, Representative for ASIAN Countries, European Medical Association, Avenue des Volontaires-191160 Brussels, Belgium, European Union

E-mail: prof.ather.emanet@gmail.com
\end{abstract}

Received: 15 Jan 2020/ Revised: 23 Feb 2020/ Accepted: 03 Mar 2020

\begin{abstract}
Background: Covid-19 is a new born sibling of the influenza family of SARS-CoV-2, named on February 11, as a new type of corona virus by the WHO. Covid-19 indicates its close relationship with activity and approaches with the SARS virus, which further triggered as epidemic in 2003 and 2004 and now similar lung triggered by SARS-CoV-2 is called Covid-19 (Corona Virus Disease 2019).

Methods: A combination of integrative therapies were administered to a 27 year old female positive with unknown SARS-CoV identified as COVID-19 with a query of coronavirus contaminated from travel history and a student of Wuhan with a respiratory congestion, integrative approach of non-invasive (ion therapy) and non-drug therapy, quantitative analysis by real time PCR, vital signs were recorded beforeand after the treatment, as all the vitals were normal and real time PCR results were monitored.

Results: The integrative therapy with isolation for 29 days from $31^{\text {st }}$ January to $27^{\text {th }}$ February was found to be satisfactory and the report, which has Real time PCR values detecting Covid-19 positive on $29^{\text {th }}$ January 2020 gave a negative result,it showed not detected and less than $35 \mathrm{Ct}$ for the test.

Conclusion: The integrative approach showed that it has high potential in treatment of Covid-19and can further imbibed in republic of china as well as other places where in 136 volunteers are part of the study and this could be an adjuvant therapy with a integrative approach for Covid-19 treatments.
\end{abstract}

Key-words: Covid-19, Emanet, Integrative medicine, Non-invasive, Non-drug, Wuhan

\section{INTRODUCTION}

Covid-19 ${ }^{[1]}$ the name, which WHO announced "COVID19 " as the name of this new disease on 11 February 2020, following guidelines previously developed with the World Organization for Animal Health (OIE) and the Food and Agriculture Organization of the United Nations (FAO). While international community on an emergency level has always witnessed the emergence of novel coronavirus-associated respiratory diseases, which

\section{How to cite this article}

Ather A, Costigliola V. Treatment and Control of Covid-19 (Corona Virus Disease 2019) By Non-invasive (h.i.p) Non-drug Therapy in Combination Anti-influenza an (Oseltamivir ( $r x$ ) Tamiflue) DrugNovel Case Report. Int. J. Life Sci., 2020; 6(2): 2480-2486.

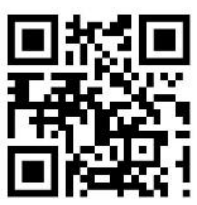

include severe acute respiratory syndrome (SARS) in 2002 to 2003 and Middle East respiratory syndrome (MERS) in 2012 to 2013 apart from this during 2014, Ebola emerged in western Africa, after 18 years of emergence of SARS, an epidemic known as coronavirus disease 2019 (COVID-19), and pertaining as it is as well caused by the novel SARS coronavirus 2 (SARS-CoV-2), these infections leading to morbidity and mortality on significant note hampering, tremendous collateral economic health care disruptions with societal costs ${ }^{[2]}$.

As on December 31, 2019, the WHO country office in China was informed of an accumulation of patients with pneumonia (pneumonia) of unknown cause in Wuhan, a city of 19 million people in Hubei Province, China ${ }^{[3]}$. A panic situation arose across the students of Asian origin in china from 26 January 2020 as media started reporting 
the hazards of the attack of a new virus leading to fatal deaths in Wuhan ${ }^{[4]}$ city of republic of china. This lead to The new corona virus SARS-CoV-2 is transferable from person to person. The main route of transmission is droplet infection. This can be done directly from person to person via the mucous membranes or indirectly via hands, which are then brought into contact with the oral or nasal mucosa and the conjunctiva ${ }^{[6]}$. Cases have also been reported in which people have become infected in those affected who have shown only mild or non-specific symptoms and henceforth isolation was very important.

\section{CASE PRESENTATION}

A 27 year old female was diagnosed positive with unknown SARS-CoV with a query of coronavirus, with a respiratory congestion, Vital signs-temperature, heart rate, respiratory rate, and blood pressure ${ }^{[7]}$ indicative towards the positive of Covid-19 ${ }^{[1]}$ was subjected to isolation in her own house. The immediate medical emergency put to her was anti influenza treatment with respirators and nebulization by Broncho dilators. This study was being support system and conducted to help and support the victim of Covid-19 ${ }^{[1]}$ after the victim volunteered herself by signing the concept to take up the study as she is a final semester medical student and the travel of non-Chinese students back to their home countries for their well being ${ }^{[5]}$.

student of Prof.Ather from china. As integrative approach of non-invasive (ion therapy) ${ }^{[8]}$ and non-drug therapy (diet, phytomedicines- 18 herbs oral consumption, inhalators and application of nasal and chest) ${ }^{[9]}$, the modus or line of treatment was a follows;

1. Anti-influenza A drug: Oseltamivir (Rx) Tamiflue [10] dose; $75 \mathrm{mg}$ PO-12 hr for 5 days, 35 mg PO- for 10 days from $1^{\text {st }}$ February 2020 to $16^{\text {th }}$ February 2020.

2. Non-invasive therapy-(-ve ion through a portable device) ${ }^{[8]}$ through a portable device supported by Dr. Ahmed Al Jaziri ${ }^{[11]}$, mode of administration was 30 minutes early morning before breakfast, ion rays passing through theback of the chest with ansemi conductor transmission on the left foot of the volunteer from $1^{\text {st }}$ February 2020 till $27^{\text {th }}$ February 2020.

3. Non-drug therapy- (Phytomedicines-18 herbs oral consumption, inhalators and application on nasal and chest) mentioned below in Table 1.

Table 1: Phytomedicines, quantity and mode of administration for control of COVID 19

\begin{tabular}{|c|c|c|}
\hline $\begin{array}{c}\text { Phytomedicine Scientific } \\
\text { Names }\end{array}$ & Quantity given & Mode and time of administration \\
\hline $\begin{array}{l}\text { Camphor }{ }^{[12]} / \\
\text { Cinnamomum camphora }\end{array}$ & $1 \mathrm{mg} /$ day & $\begin{array}{l}\text { Mixed along with thymol and menthol and applied to the nose } \\
\text { and chest }\end{array}$ \\
\hline Menthol ${ }^{[13]}$ & $1 \mathrm{mg} /$ day & $\begin{array}{l}\text { Mixed along with thymol and camphor and applied to the nose } \\
\text { and chest }\end{array}$ \\
\hline Thymol ${ }^{[14]}$ & $1 \mathrm{mg} /$ day & $\begin{array}{l}\text { Mixed along with camphor and menthol and applied to the nose } \\
\text { and chest }\end{array}$ \\
\hline Zingiber officinale ${ }^{[15]}$ & $500 \mathrm{mg} /$ day & $\begin{array}{l}\text { Powder of Zingiber officinale extract filled in a capsule at } 6.00 \\
\text { Hrs }\end{array}$ \\
\hline Curcuma longa ${ }^{[16]}$ & $500 \mathrm{mg} /$ day & Powder of Curcuma longa extract filled in a capsule at $6.00 \mathrm{Hrs}$ \\
\hline Azadirachta indica ${ }^{[17]}$ & $500 \mathrm{mg} /$ day & $\begin{array}{c}\text { Powder of Azadirachta indica extract filled in a capsule at } 06.00 \\
\text { Hrs with one cup of warm water before breakfast }\end{array}$ \\
\hline Momordica charantia ${ }^{[18]}$ & $500 \mathrm{mg} /$ day & $\begin{array}{l}\text { Powder of Momordica charantia extract filled in a capsule at } \\
06.00 \mathrm{Hrs} \text { with one cup of warm water before breakfast }\end{array}$ \\
\hline Hibiscus rosa-sinensis ${ }^{[19]}$ & $500 \mathrm{mg} /$ day & $\begin{array}{l}\text { Powder of Hibiscus rosa-sinensis extract filled in a capsule at } \\
08.00 \mathrm{Hrs} \text { with one cup of warm water after breakfast }\end{array}$ \\
\hline Bacopa monnieri ${ }^{[20]}$ & $500 \mathrm{mg} /$ day & $\begin{array}{l}\text { Powder of Bacopa monnieri extract filled in a capsule at } 08.00 \\
\text { Hrs with one cup of warm water after breakfast }\end{array}$ \\
\hline Tinospora cordifolia ${ }^{[21]}$ & $500 \mathrm{mg} /$ day & Powder of Tinospora cordifolia extract filled in a capsule at 11.00 \\
\hline
\end{tabular}




\begin{tabular}{|c|c|c|}
\hline Withania somnifera ${ }^{[22]}$ & 500 mg/day & $\begin{array}{l}\text { Powder of Withania somnifera extract filled in a capsule at } 11.00 \\
\text { Hrs with one cup of warm water }\end{array}$ \\
\hline Murraya koenigii ${ }^{[23]}$ & 500 mg/day & $\begin{array}{l}\text { Powder of Murraya koenigii extract filled in a capsule at } 14.00 \\
\text { Hrs with one cup of warm water after lunch }\end{array}$ \\
\hline Moringa oleifera ${ }^{[24]}$ & 500 mg/day & $\begin{array}{l}\text { Powder of Moringa oleifera extract filled in a capsule at } 14.00 \\
\text { Hrs with one cup of warm water after lunch }\end{array}$ \\
\hline Saraca asoca ${ }^{[25]}$ & 500 mg/day & $\begin{array}{l}\text { Powder of Saraca asoca extract filled in a capsule at } 16.00 \mathrm{Hrs} \\
\qquad \text { with one cup of warm water }\end{array}$ \\
\hline Areca catechu ${ }^{[26]}$ & 500 mg/day & $\begin{array}{l}\text { Powder of Areca catechu extract filled in a capsule at } 16.00 \mathrm{Hrs} \\
\text { with one cup of warm water }\end{array}$ \\
\hline Glycyrrhiza glabra & 500 mg/day & $\begin{array}{c}\text { Powder of Glycyrrhiza glabra extract filled in a capsule at } 20.00 \\
\text { Hrs with one cup of warm water after dinner }\end{array}$ \\
\hline Santalum album [28] & 500 mg/day & $\begin{array}{l}\text { Powder of Santalum album extract filled in a capsule at } 20.00 \\
\text { Hrs with one cup of warm water after dinner }\end{array}$ \\
\hline Pistacia lentiscus ${ }^{[29]}$ & 500 mg/day & $\begin{array}{l}\text { Powder of Pistacia lentiscus extract filled in a capsule at } 20.00 \\
\text { Hrs with one cup of warm water after dinner }\end{array}$ \\
\hline Ginkgo biloba ${ }^{[30]}$ & 500 mg/day & $\begin{array}{l}\text { Powder of Ginkgo biloba extract filled in a capsule at } 20.00 \mathrm{Hrs} \\
\text { with one cup of warm water after dinner }\end{array}$ \\
\hline $\begin{array}{l}\text { igonella foenum-graecum } \\
\qquad[31]\end{array}$ & 500 mg/day & $\begin{array}{l}\text { Powder of Trigonella foenum-graecum extract filled in a capsule } \\
\text { at } 20.00 \mathrm{Hrs} \text { with one cup of warm water after dinner }\end{array}$ \\
\hline Tamarindus indica & $500 \mathrm{mg} / \mathrm{day}$ & $\begin{array}{l}\text { Powder of Tamarindus indica extract filled in a capsule at } 22.00 \\
\text { Hrs with one cup of warm water after before sleep }\end{array}$ \\
\hline Eculyptus oil [33] & 500 mg/day & $\begin{array}{c}\text { Soft gel capsule with at } 22.00 \text { Hrs with one cup of warm water } \\
\text { before sleep }\end{array}$ \\
\hline
\end{tabular}

The use of real-time RT PCR (rRT-PCR) assays for the in vitro qualitative detection of 2019-Novel Coronavirus (2019-nCoV) in respiratory specimens and sera and hematological investigations we observed and recorded, it was before the start of the treatment and when there was a detection the below Table 2 signifies the values and its reference range which was recorded before the treatment.

After duration of 28 days from 1st February 2020 to 27th February 2020 it was observed that the $\mathrm{Ct}$ values reduced in the real time $\mathrm{PCR}$, along with increase in $\mathrm{Hb} \%$ and increase in the platelets. The readings are indicted in Table 3.

Table 2: Laboratory data of the patient on $31^{\text {st }}$ January 2020 a real time PCR test was performed with other hematological test

\begin{tabular}{cccc}
\hline Examination & Observed value & Unit & Reference range \\
\hline Real Time PCR & 42Ct for test & $\mathrm{Ct}$ & Ranges from 150,000 to 450,000 \\
Platelet & 100,000 & gms for Test \\
Hb\% & 9 & & $13-14$ gms $\%$ \\
\hline
\end{tabular}


Table 3: Laboratory data of the patient $27^{\text {th }}$ February 2020

\begin{tabular}{cccc}
\hline Examination & Observing value & Unit & Reference range \\
\hline Real Time PCR & $22 \mathrm{Ct}$ for test & $\mathrm{Ct}$ & $>35 \mathrm{Ct}$ for Test \\
Platelet & 430,000 & & Ranges from 150,000 to 450,000 \\
$\mathrm{Hb} \%$ & 14 & gms\% & $13-14 \mathrm{gms} \%$ \\
\hline
\end{tabular}

\section{DISCUSSION}

The treatment of COVID 19 is challenging, although management and treatment have been possible by antiviral activity of compounds based on camphor ${ }^{[34]}$. Even as Anti-influenza A drug: Oseltamivir (Rx) Tamiflue [35] have been used without a doubt there are innumerous ways to find management and treatment of COVID 19 as of now the major concern is the outbreak and isolation which is hampering the day to day activities leading to an economic outbreak of societies and stands as a social stigma on individuals. At this time of interment crises the focus on saturating a single cause like a simple ionizing device operating at 12 volt that can prevent spread of airborne transmitted viral infections between populations and in individuals in a controlled setting, whilst simultaneously collecting virus from air for rapid identification ${ }^{[36]}$.

By understanding that a negative ion is an oxygen atom, featuring one extra electron and coupled with sensitive RT-qPCR assays, this sampling method enabled fast detection and highly sensitive quantification of several human clinically important viruses such as influenza virus, rotavirus and calicivirus. At this juncture the device consisting of a small portable ionizer helps in breaking the virus with high robustness as well as the wide applicability to airborne pathogens. Inactivation of viruses by electrostatic attraction has only been briefly investigated ${ }^{[35]}$. In the present study, rotavirus and $\mathrm{CaCV}$ lost significance (>97\%) infectivity (ratio; $\mathrm{CaCV}$ from $3.0 \times 10^{-2}$ to $<7.8 \times 10^{-4}$ and rotavirus from $4.9 \times 10^{-1}$ to $<7.6 \times 10^{-3}$ ) in the ionized air as determined by a ratio of infectivity versus gene copies. The mechanism of inactivation was not explicitly investigated in this study, but inactivation mechanisms may include reactive species and/or increased protein charge levels, which could inactivate virus as previously described [37]. Reduced infectivity has been proposed to be due to reactive oxygen species and ozone, through lipid- and protein peroxidation reactions that may cause damage and destruction to the viral lipid envelope and protein capsid. Along with the virus breakage if the immunity is raised with immune-modulators of phyto extracts ${ }^{[38]}$ and anti-influenza drugs which can kill the virus infection ${ }^{[39]}$.

\section{CONCLUSIONS}

The intensity of contamination is spreading across the globe and a need for further research is emphasized so that we can ascertain the exact treatment for COVID 19 , this can be a unique and faster mode of treatment by noninvasive procedures like hyper ion plasma (H.I.P), which can be portable devices for a person which can be carried home for an individual or it can be a hospital or clinic establishment which can ascertain that noninvasive method can be an adjuvant therapy in general or treatment as complete solution by itself for this we have to further conduct studies with multiple clinical centers and multiple groups along with a control group.

Mode of treatment for COVID 19 is anti-influenza drug Oseltamivir (Rx), which varies from $75 \mathrm{mg}$ per day to start to $35 \mathrm{md}$ per day, we need to ascertain the exact mechanism of negative ion inactivation of viruses which can be possible by giving ion therapy with controlled studies and along with it as dose escalation needs to be ascertain what was the exact modes of termination of the virus in the above case and it is premature to conclude from an individual case that what exactly works and as Professor Gérard Krause from the Helmholtz Center for Infection Research warns against too high expectations this case is as well an examples along with the individual case reported from Thailand, it cannot be concluded that this would also work for other patients.

\section{ACKNOWLEDGMENTS}

Firstly, I would thank the victim to give her concent to publish the study and in taken into consideration of the social stigma around and will not disclose her identity at any circumstances. The authors are indepted to the 
board of thee European Medical Association, Avenue des Volontaires, 19,1160 Brussels, European Union for supporting in the publication of the case report.

\section{CONTRIBUTION OF AUTHORS}

Research concept- Prof.em.Dr.Amina Ather

Research design- Prof.em.Dr.Amina Ather

Supervision-Dr. Vincenzo Costigliola

Materials- Prof.em.Dr.Amina Ather

Data collection- Prof.em.Dr.Amina Ather

Data analysis and interpretation- Prof.em.Dr.Amina Ather

Literature search- Prof.em.Dr.Amina Ather

Writing article- Prof.em.Dr.Amina Ather

Critical review- Dr. Vincenzo Costigliola

Article editing- Prof.em.Dr.Amina Ather

Final approval- Prof.em.Dr.Amina Ather

\section{REFERENCES}

[1] World health organization. Naming the coronavirus disease (COVID-19) and the virus that causes it, Novel coronavirus (2019-ncov) situation report-22 Updated on 11 February 2020. Available from https://www.who.int/docs/defaultsource/coronaviruse/situation-reports/20200211sitrep-22-ncov.pdf.

[2] Perl TM, Price CS. Managing Emerging Infectious Diseases: Should Travel Be the Fifth Vital Sign? Ann. Intern. Med., 2020; pp. 1-3. doi: https://doi.org/10.7326/M20-0643.

[3] Bundesministerium fur Gesundheit. Tagesaktuelle Informationen zum Coronavirus. https://www.bunde sgesundheitsministerium.de/coronavirus.html.

Assessed on 03-03-2020.

[4] Berlinger J, McKeehan B, John T. January 26 Coronavirus News. Asian Live streaming by CNN Updated 9:17 p.m. ET, January 26, 2020. https://edition.cnn.com/asia/live-news/coronavirusoutbreak-hnk-intl-01-26-20/index.html.

[5] Support The Guardian. China promises tougher crackdown to stop spread of disease-as it happened. Updated on 26 Jan 2020. Available on https://www.theguardian.com/science/live/2020/ja n/26/corona virus-outbreak-death-toll-rises-to-54as-canada-confirms-first-case.

[6] BBC news. Coronavirus: death toll rises as virus spreads to every Chinese region. Updated on 30-01-
2020. Available on https://www.bbc.com/news/ world-asia-china-51305526.

[7] Diebold SS, Kaisho T, Hiroaki H, Akira S, et al. Innate Antiviral Responses by Means of TLR7-Mediated Recognition of Single-Stranded RNA. Sci., 2004; 303: 1529-31. doi: 10.1126/science.1093616.

[8] Edberg SC. Global infectious diseases and epidemiology network (gideon): a world wide webbased program for diagnosis and informatics in infectious diseases. Clinic. Infect. Dis., 2005; 40: 12336.

[9] Hagbom M, et al. lonizing air affects influenza virus infectivity and prevents airborne-transmission. Sci. Rep., 2015; 5: 11431. doi: 10.1038/srep11431.

[10]Grippe S. Oseltamivir (Tamiflu) vorkomplikationen? Gesundheitsinformation.de. Updated on 03-02-2020. https://www.gesundheitsinformation.de/schuetztoseltamivir-tamiflu-vor-komplikationen.2352.de. html?Part=behandlung-gy-6cvt-rjzz.

[11] Hamdan Award for Honouring Individuals Working in the Field of Medicine \& Health. Dr. Ahmad abdulaziz al jaziri. Updated on 27-01-2020. http://hmaward. org.ae/profile.php?ld=1611.

[12]Zarubaev VV, Pushkina EA2, Borisevich SS3, Galochkina AV, et al. Selection of influenza virus resistant to the novel camphor-based antiviral camphecene results in loss of pathogenicity. Virol., 2018; 524: 69-77. doi: 10.1016/j.virol.2018.08.011.

[13]Vaghasiya $Y$, Nair R, Chanda S. Antibacterial and preliminary phytochemical and physico-chemical analysis of Eucalyptus citriodora $\mathrm{Hk}$ leaf. Natural Product Res., 2008; 22: 9: 754-62.

[14]Matti A. Antibiotics and Sensorineural Interactions In vitro Studies. Acta Oto-Laryngologica, 1986; 101: 1721.

[15]Nogueira de Melo GA, Grespan R, Fonseca JP, Farinha TO, et al. Inhibitory effects of ginger (Zingiber officinale Roscoe) essential oil on leukocyte migration in vivo and in vitro. J Nat. Med., 2011; 65: 241-44.

[16]WHO. Prevention and Control of Dengue and Dengue Haemorrhagic Fever Revised and expanded. 2011; pp. 17-28.

[17] Imrana I, Altafb I, Ashrafa M, Javeeda A, et al. In vitro evaluation of antiviral activity of leaf extracts of Azadirachta indica, Moringa oleifera, and Morus alba 
against the foot and mouth disease virus on BHK-21 cell line. Scienceasia, 2016; 42: 392-96.

[18]Pongthanapisith V, Ikuta K, Puthavathana P, et al. Antiviral Protein of Momordica charantia L. Inhibits Different Subtypes of Influenza A. Evid Based Complement Alternat. Med., 2013; pp. 1-6.

[19]Gupta V, Bansal P, Garg A, Meena AK. Pharmacopoeial Standardization of Hibiscus rosa sinensis Linn. Inter. J. Pharm. Clin. Res., 2009; 1(3): 124-26.

[20]Kure C, Timmer J, Stough C. The immunomodulatory effects of plant extracts and plant secondary metabolites on chronic neuroinflammation and cognitive aging: a mechanistic and empirical review. Frontiers Pharmacol., 2017; 8: 1-12.

[21]Astro-Logisch. www.bfr.bund.de. Gesundheitliche Beeinträchtigungen durch Guduchi-Kräutertees sind möglich-Datenlage ist aber noch unzureichend. 2013; pp. 1-16.

[22] Withania somnifer information about uses on it. Accessed on 28-01-2020. Available on https://www.bunkahle.com/kraeuter/pflanzenbesch reibungen/schlafbeere.pdf.

[23]Nishan M, Subramanian P. Murraya koenigii (curry leave)- A review on its potential. Inter. J. PharmTech. Res., 2014-2015; 7(4): 566-72.

[24]/n vitro evaluation of antiviral activity of leaf extracts of Azadirachta indica, Moringa oleifera, and morusalba against the foot and mouth disease virus on bhk-21 cell line. Accessed on 28-01-2020. Available

on http://www.scienceasia.org/2016.42.n6/scias42_392 .pdf accessed on 28001-2020.

[25]Nag D, Ghosh M, Mukherjee A. Antimutagenic and genoprotective effects of Saraca asoca bark extract. Toxicol. Ind. Health, 2015; 31(8): 696-703.

[26]Lee D, Boo KH, Kim YC, Lee JM, Kang S, et al. The antiviral effects of Areca catechu L. Extract. Korean J. Food Sci. Technol., 2014; 46(2): 245-248.

[27]Buch C, Jagel A. Glycyrrhiza glabra-süßholz (fabaceae), Arzneipflanze des Jahres 2012. Jahrb. Bochumer Bot. Ver., 2013; 4: 187-190.

[28]Mohankumar A, Shanmugam G, Kalaiselvi D, Levenson C, Nivitha $S$, et al. East Indian sandalwood (Santalum album L.) oil confers neuroprotection and geroprotection in Caenorhabditis elegans via activating SKN-1/Nrf2 signaling pathway. RSC Adv., 2018; 8: 33753-74.

[29]Ozçelik B, AslanM, Orhan I, Karaoglu T. Antibacterial, antifungal, and antiviral activities of the lipophylic extracts of Pistacia vera. Microbiol. Res., 2005; 160: 159-64.

[30]Biloba G. Accessed on 28-01-2020. Available on https://www.thelancet.com/action/showpdf?Pii $=014$ 0-6736\%2892\%2993158-j.

[31]PCT-The International Patent System. International application published under the patent cooperation treaty (PCT). Accessed on 28-01-2020. https://patentimages.storage.googleapis.com/10/f4/ 9e/b08e1da023400d/wo2017013568a1.pdf.

[32] Kuru P. Tamarindus indica and its health related effects. Asian Pacific J. Trop. Biomed., 2014; 4(9): 676-81.

[33]Abu-Jafar A, Huleihel M. Antiviral activity of Eucalyptus camaldulensis leaves ethanolic extract on herpes viruses infection. Int. J. Clin. Virol., 2017; 1: 001-09.

[34]Zarubaev VV, Lavrentieva IN, Yarovaya O, et al. Development of a new anti-influenza compound based on camphor scaffold. New Chemother. infec. Dis., 2018; 8: 4.

[35] Latest drug news-Updates and news releases on prescription medications and drug manufacturing/ distribution. Accessed on 02-03-2020. Available on https://www.rxlist.com/tamiflu-drug.htm.

[36] Ion Loop. Understand Ion Technology As A Possible Aid To Avoid The Flu. Accessed on 02-03-2020. Available on https://www.ionloop.com/blog/ understand-ion-technology-as-a-possible-aid-toavoid-the-flu/.

[37]Murray BK, Ohmine S, Tomer DP, Jensen KJ, Johnson $\mathrm{FB}$, et al. Virion disruption by ozone-mediated reactive oxygen species. J Virol Methods, 2008; 153(1): 74-77. doi: 10.1016/j.jviromet.2008.06.004.

[38]Ahmad I, Aqil F, Owais M. Immunomodulatory Effects of Phytocompounds. Modern Phytomedicine: Turning Medicinal Plants into Drugs. ${ }^{\text {st }}$ Ed. published on 20 September 2006. doi: https://doi.org/ 10.1002/9783527609987.ch16.

[39] Estola T, Makela P, Hovi T. The effect of air ionization on the air-borne transmission of experimental Newcastle disease virus infections in chickens. J. Hyg., Camb., 1979; 83: 59-67. 


\section{Open Access Policy:}

Authors/Contributors are responsible for originality, contents, correct references, and ethical issues. SSR-IIJLS publishes all articles under Creative Commons Attribution- Non-Commercial 4.0 International License (CC BY-NC). https://creativecommons.org/licenses/by-nc/4.0/legalcode (c) (1) (9) 